\title{
PERLINDUNGAN BURUH MIGRAN FILIPINA DALAM KONSTITUSI
}

\author{
DITTA GIARNI MARTHA \\ Prodi Hukum Universitas Satya Negara Indonesia \\ dittagiarni29@yahoo.com
}

\begin{abstract}
The Philippines is a country that has a good migrant worker management system. Based on Article 13 of the Philippine Constitution states that the state through the authority of the Human Rights Commission guarantees appropriate legal action for the protection of the human rights of all people in the Philippines as well as Filipinos working abroad. The research method in this paper uses the normative legal research method. This research method is a method that uses and analyzes written regulations which are closely related to the library. The research result of this paper is that the POEA is fully responsible to its President through the Minister of Manpower. The POEA's relationship with other institutions related to the protection of migrant workers is sub-coordinative. POEA is the mother for the protection of migrant workers. Legal protection agencies or agencies for migrant workers in the Philippines are maximizing the roles of the Philipine Overseas Employment Agency (POEA), Overseas Workers Welfare Administration (OWWA) and The Office of the Legal Assistant for Migrant Affairs (OLAMA). Where the POEA is assigned to monitor and supervise recruitment agencies in the Philippines, the OWWA provides Filipino migrant workers and their families with all the assistance they may need in enforcing contractual obligations by agencies or agencies and / or their principals, and OLAMA has the duty and authority to assist and protect who get unfair treatment, both physically and psychologically.
\end{abstract}

Keywords: Protection, Migrant Workers, Philippines.

Abstrak: Filipina adalah suatu negara yang mempunyai sistem pengelolaan tenaga kerja migran yang baik. Berdasarkan Pasal ke-13 Konstitusi Filipina menyebutkan bahwa negara melalui kewenangan Komisi Hak Asasi Manusia menjamin tindakan hokum yang tepat untuk perlindungan hak asasi manusia semua orang di Filipina serta orang Filipina bekerja di luar negeri.. Metode penelitian dalam tulisan ini menggunakan metode penelitian hukum normatif. Metode penelitian ini adalah metode yang menggunakan dan menganalisa peraturan - peraturan tertulis yang sangat erat hubungannya pada perpustakaan. Hasil penelitian dari tulisan ini adalah Badan atau lembaga perlindungan hukum bagi buruh migrant di Filipina adalah memaksimalkan peran dari Philipine Overseas Employment Agency (POEA), Overseas Workers Welfare Administration (OWWA) dan The Office of the Legal Assistant for Migrant Affairs (OLAMA). Dimana POEA ditugaskan untuk memantau dan mengawasi agen perekrutan di Filipina, OWWA yang menyediakan pekerja migran Filipina dan keluarganya semua bantuan yang mereka mungkin perlu dalam penegakan kewajiban kontrak oleh lembaga atau badan dan / atau mereka prinsipal, dan OLAMA memiliki tugas dan kewenangan untuk membantu dan melindungi yang mendapatkan perlakuan yang tidak adil, baik secara fisik maupun secara psikis.

Kata Kunci: Perlindungan, Buruh Migran, Filipina.

\section{A. Pendahuluan}

Tenaga kerja Filipina menjadi bagian amat penting bagi masyarakat dan ekonomi negeri ini. Pemerintah menyebutnya OFW (Overseas Philippines Workers) sebagai E-ISSN: 2657-0300 Lembaga Penelitian dan Penerbitan Hasil Penelitian Ensiklopedia 289 P-ISSN: 2657-0319 
pahlawan negara - mba bagong bayani - terutama karena kiriman uang dari mereka menjadi bagian penting pendapatan dalam negara. Terminologi OFW mencakup beragam kelompok tenaga kerja Filipina yang mengais rejeki di luar negeri: mereka dapat saja warga Filipina yang menjadi penduduk permanen di luar negeri atau pekerja kontrak, tercatat atau tidak tercatat.

Undang-undang pertama kali yang mengatur tenaga kerja Filipina adalah Undang-Undang No 442 Tahun 1974 Tentang Perburuhan, yang ditetapkan pada tanggal 4 Mei 1974. Selain itu, undang-undang untuk Filipina di luar negeri yang berlaku, yaitu Undang-Undang Voting Overseas Absentee dari 2003 (RA 9189) yang memungkinkan Filipina di luar negeri untuk berpartisipasi dalam pemilihan nasional di Filipina tanpa hadir secara fisik di Filipina. Hukum namun tidak termasuk partisipasi mereka dalam plebisit dan referendum. Oleh karena itu kecuali inisiatif saat ini untuk mengubah RA9189 mendorong melalui, Filipina di luar negeri tidak dapat berpartisipasi dalam referendum mendatang untuk mengubah konstitusi.

Kerja kebijakan ekspor pemerintah lebih lanjut ditegaskan oleh menyodorkan Program POEA untuk 2008 yang termasuk "fasilitasi penyebaran OFW" melalui partisipasi dalam tingkat tinggi misi pemasaran teknis, intelijen pasar intensif bekerja di luar negeri dalam rangka untuk mencari peluang nilai kerja tinggi dan mengidentifikasi baru / pasar negara berkembang, partisipasi dalam menempa perjanjian bilateral dengan pemerintah setempat yang dapat menawarkan pekerjaan baru dan layak untuk OFW, kunjungan mendorong pemerintah asing dan perusahaan swasta delegasi ke Filipina, hubungan dengan memperkuat sektor kebugaran pendidikan, pelatihan dan medis untuk menghasilkan kualitas yang tepat dan kuantitas kontrak yang dibutuhkan oleh pasar luar negeri, dan, meningkatkan kerja dengan pemerintah tuan rumah untuk plug rute migrasi tidak teratur dan mencegah pengelakan persyaratan penyebaran.

Asone petugas dari International Labor Affairs Services (ILAS) di Departemen Tenaga Kerja dan Ketenagakerjaan (DOLE) mengakui, masalah singkat selama CMA, 19 September 2008 telah diselenggarakan forum publik kuartalan berjudul "Filipina: Sebuah Model Global untuk Migrasi" yang semata-mata jumlah OFW membuat mustahil bagi instansi pemerintah untuk mengatasi kebutuhan dan masalah. The ILAS latihan yurisdiksi administratif atas Filipina Kantor Tenaga Kerja Luar Negeri (POLOS). Isu dan Tren tentang Migrasi Tenaga Kerja Filipina.

Filipina sebagai negara pihak Konvensi PBB tentang Penghapusan Segala Bentuk Diskriminasi (CEDAW, 2006) dan Hak Semua Pekerja Migran dan Anggota Keluarganya (CMW, 2009), komite perjanjian mendesak pemerintah Filipina untuk menghormati, melindungi, dan memenuhi hak-hak perempuan, dan untuk melindungi perempuan dari menjadi korban lintas-perbatasan kegiatan perdagangan manusia.

\section{B. Metodologi Penelitian.}

Penelitian ini dilakukan untuk mengetahui Perlindungan Buruh Migran Filipina Dalam Konstitusi.

\section{Hasil dan Pembahasan}

C.F. Strong memberikan pengertian konstitusi suatu kumpulan asas-asas yang menyelenggarakan kekuasaan pemerintahan (arti luas), hak-hak dari pemerintah dan hubungan antara pemerintah dan yang diperintah (menyangkut hak-hak asasi manusia). 
Dengan demikian konstitusi adalah sebagai kerangka negara yang diorganisir dengan dan melalui hukum yang menetapkan: 1) pengaturan mengenai pendirian lembagalembaga yang permanen, 2) Fungsi-fungsi dari alat-alat perlengakapan negara dan 3) Hak-hak tertentu yang telah ditetapkan. Pada intinya kedudukan konstitusi dalam suatu negara bisa di bedakan kepada dua aspek, yaitu:

1. Aspek Hukum. Konstitusi dilihat dari aspek hukum mempunyai derajat tertinggi dari aturan hukum yang ada karena beberapa pertimbangan, yaitu: a) Konstitusi dibuat oleh Badan Pembuat Undang-Undang atau Lembaga Negara; b) Konstitusi dibentuk atas nama rakyat, dari rakyat dan kekuatan berlakuknya dijamin oleh rakyat dan dilaksanakan untuk kepentingan rakyat pula; c) Konstitusi dibuat oleh badan yang diakui keabsahannya; dan d) Dayat ikatnya bukan saja kepada rakyat tetapi juga kepada penguasa dan pembuat konstitusi itu sendiri.

2. Aspek Moral. Konstitusi dibuat berdasarkan landasan etika moral dan nilai-nilai yang bersifat universal. Moral dan nilai-nilai universal setiap waktu dapat mengontol konstitusi agar konstitusi dapat menyesuaikannya. Contohnya konstitusi yang melegalisir sistem apartheid dengan sendirinya ia bertentangan dengan moral dan akan mendapat kritik dan sorotan dari masyarakat secara umum. Adapun motif politik yang menonjol dari penyusunan UUD menurut Bryce adalah sebagai berikut: a) Keinginan untuk menjamin hak-hak rakyat dan untuk mengendalikan tingkah laku penguasa; b) Keinginan untuk menggambarkan sistem pemerintahan yang ada dalam rumusan yang jelas guna mencegah kemungkinan perbuatan sewenang-wenang dari penguasa di masa depan; c) Hasrat dari pencipta kehidupan politik baru untuk menjamin atau mengamankan berlakunya cara pemerintahan dalam bentuk yang permanen dan yang dapat dipahami oleh warga negara; d) Hasrat dari masyarakat - masyarakat yang terpisah untuk menjamin aksi bersama yang efektif dan bersamaan dengan itu berkeinginan tetap mempertahankan hak serta kepentingannya sendiri-sendiri.

Dalam Pasal XIII Konstitusi Filipina mengungkapkan tanggung jawab penuh Kongres untuk memberikan prioritas tertinggi dalam pemberlakuan tindakan-tindakan yang melindungi dan meningkatkan hak-hak semua orang atas martabat manusia melalui penegasan bahwa ketidaksetaraan sosial, ekonomi dan politik serta ketidakadilan budaya di antara para elit. dan kaum miskin akan dikurangi atau disingkirkan untuk menjamin kesejahteraan yang adil dan kebaikan bersama di antara rakyat Filipina. Ini juga menetapkan peran Komisi Hak Asasi Manusia yang menjamin tindakan hukum yang tepat untuk perlindungan hak asasi manusia semua orang di Filipina serta orang Filipina yang tinggal di luar negeri. Selain itu, bagian ini juga menetapkan ketentuan-ketentuan penting seperti: a) Perlindungan tenaga kerja, baik di dalam maupun di luar negeri untuk mempromosikan pekerjaan penuh dan kesempatan yang sama bagi semua; b) Perlindungan hak dan pemberian dukungan kepada petani dan nelayan Filipina yang mandiri di kalangan masyarakat lokal untuk pemanfaatan sumber daya mereka tanpa gangguan asing, bersama dengan penyediaan dan penerapan Pembaruan Agraria dan Sumber Daya Alam untuk pembangunan kehidupan masyarakat; c) Mengamankan kehidupan di antara warga yang kurang mampu melalui Reformasi Tanah dan Perumahan Perkotaan; d) Adopsi dan integrasi perawatan medis dan layanan kesehatan yang terjangkau dan kompeten untuk kesejahteraan setiap orang Filipina; e) Pengakuan hak-hak perempuan di tempat kerja atas realisasi potensi penuh mereka dalam memberikan layanan kepada bangsanya; f) Pengakuan peran dan hak organisasi masyarakat. 
Pasal 18 dari Undang-Undang Tenaga Kerja melarang mempekerjakan langsung dari seorang pekerja untuk penempatan di luar negeri. Aturan ini dimaksudkan untuk melindungi pelamar dari penjahat yang tidak bermoral dengan mengatur perekrutan melalui agen berlisensi dan terdaftar. Agen perekrutan diperbolehkan untuk mengumpulkan dari pekerja biaya penempatan tidak melebihi setara dengan satu bulan gaji-pemohon. Mereka juga dapat mengumpulkan biaya layanan dari majikan asing. Selain biaya penempatan, pekerja migran membayar biaya berikut: Paspor, NBI / Polisi / Barangay Clearance, Otentikasi, Akte Kelahiran, Asuransi Kesehatan Medis Filipina (Philhealth), uji Dagang, jika perlu, Inokulasi, bila diperlukan oleh negara tuan rumah dan Pemeriksaan medis Biaya.

Pasal 280 dari Kode Tenaga Kerja dari Filipina menjelaskan berbagai jenis pekerjaan yaitu: reguler, kasual, proyek atau musiman. Perbedaan ini penting karena beberapa hak dan manfaat melampirkan hanya untuk karyawan tetap, khususnya hak atas keamanan kepemilikan. Jenis yang paling umum dari pekerjaan sekarang adalah kerja jangka tetap atau kontrak. Sebagian besar perusahaan lebih memilih untuk menghemat biaya tenaga kerja karena jika mereka mempekerjakan karyawan biasa, mereka tidak bisa menghentikan pekerjaan mereka expediently tanpa sebab yang sah dan legal dan pembayaran pesangon dan tunjangan lainnya.

Pada tahun 2010, Undang-Undang Republik Nomor 10022 diubah beberapa ketentuan, termasuk yang dikutip di atas. Diantara perubahan lain, paragraf mendefinisikan pekerja Migran istilah diubah sehingga berbunyi, "'Overseas Filipina pekerja merujuk kepada seseorang yang akan terlibat, bergerak atau telah terlibat dalam pekerjaan yang dibayar dalam keadaan yang ia bukan warga negara atau di papan kapal navigasi laut asing selain kapal pemerintah yang digunakan untuk tujuan militer atau non-komersial atau pada instalasi lepas pantai atau berada di laut lepas,. untuk digunakan bergantian dengan pekerja migran ", dan teks pengantar mengenai penyebaran diubah untuk membaca, "Negara harus memungkinkan penyebaran pekerja Filipina di luar negeri hanya di negara-negara di mana hak-hak pekerja migran Filipina dilindungi.

\section{Bentuk dan Sistem Kelembagaan Perlindungan Tenaga Kerja di luar negeri Negara Filipina}

a. Philipine Overseas Employment Agency (POEA)

Administrasi Ketenagakerjaan Luar Negeri Filipina (POEA) adalah lembaga Pemerintah Filipina bertanggung jawab untuk membuka manfaat dari program kerja luar negeri Filipina. Ini adalah agen utama pemerintah yang ditugaskan untuk memantau dan mengawasi agen perekrutan di Filipina. Kantor POEA ini terletak di sudut EDSA Ortigas Avenue, Mandaluyong City, Filipina. POEA didirikan pada tahun 1982 melalui No Executive Order 797. Tujuan dari pembentukan lembaga ini adalah untuk mempromosikan dan memantau pekerjaan di luar negeri dari para pekerja Filipina. POEA direorganisasi pada tahun 1987 melalui No Executive Order 247 dalam rangka merespon perubahan pasar dan kondisi ekonomi, dan untuk memperkuat komponen yang akan melindungi pekerja Filipina dan komponen regulasi dari program pekerjaan luar negeri.

Pada tanggal 1 November 2011, POEA Governing Board (GB) diterbitkan No.7 Resolusi GB, yang menetapkan daftar dari 41 negara di mana OFW tidak dapat digunakan untuk non-kepatuhan dengan jaminan yang disyaratkan dalam RA 10022. 
Seperti November 2011 POEA daftar 125 negara sebagai jaminan sesuai dengan yang dipersyaratkan dalam RA 10022. POEA memiliki tiga (3) Pusat Regional yang terletak di La Union untuk Luzon, Cebu untuk wilayah Visayas dan Davao untuk wilayah Mindanao. Unit Perpanjangan Daerah berada di Baguio-Cordillera Region Administrasi, Iloilo, Cagayan de Oro dan Zamboanga, sementara satelit kantor-kantor terletak di Pampanga, Calamba, Laguna, Legaspi, Bacolod dan Tacloban.

Beberapa fungsi POEA yaitu: 1) Masalah lisensi untuk terlibat dalam perekrutan luar negeri dan berjaga ke agen perekrutan swasta dan perusahaan kapal pengawakan; 2) Mendengar dan mengadili pengaduan dan kasus diajukan terhadap agen perekrutan dan awak, prinsipal asing dan pengusaha, dan pekerja luar negeri untuk pelanggaran yang dilaporkan aturan POEA dan peraturan, kecuali untuk klaim uang; 3) Menerapkan sistem insentif dan hukuman untuk peserta sektor swasta; 4) Menetapkan standar perburuhan minimum; 5) Monitor iklan lowongan kerja di luar negeri pada cetak, siaran dan televise; 6) Mengawasi program pemerintah tentang anti-ilegal rekrutmen; 7) Memberlakukan tindakan disiplin pada pengusaha berdosa dan pekerja dan pelaut Pekerjaan Fasilitasi; 8) Akreditasi / register prinsipal asing dan pengusaha mempekerjakan pekerja Filipina; 9) Permintaan tenaga Menyetujui kepala asing dan majikan; dan 10) Mengevaluasi dan memproses kontrak kerja

\section{b. Overseas Workers Welfare Administration (OWWA)}

Merupakan Petugas Kesejahteraan atau dalam ketidakhadirannya, petugas koordinasi harus menyediakan pekerja migran Filipina dan keluarganya semua bantuan yang mereka mungkin perlu dalam penegakan kewajiban kontrak oleh lembaga atau badan dan / atau mereka prinsipal. Dalam melaksanakan fungsi ini, ia akan membuat representasi dan dapat memanggil lembaga atau badan yang bersangkutan untuk konferensi atau pertemuan konsiliasi untuk tujuan penyelesaian keluhan atau masalah dibawa ke perhatiannya. Dengan mengikuti jalan legal, calon tenaga kerja akan dapat subsidi manfaat (1) pelatihan dan orientasi budaya di tempat baru, (2) asuransi jiwa/jaminan pensiun, (3) asuransi kesehatan, (4) berhak atas dana darurat. Untuk ini tenaga kerja migran dikenakan biaya 200 dolar per tahun (2008), ini dilakukan oleh OWWA (Overseas Workers Welfare Administration).

Tenaga kerja migran dapat semacam kartu (untuk memudahkan urusan administrasi, dan kartu individu mendapatkan secara gratis). Fungsi kartu itu antara lain (1) pemegang kartu itu sebagai bukti diri bahwa dia pekerja migran Pilipina yang sah, (2) nomor kartu mempunyai link informasi penting baik ke badan-badan pemerintah maupun swasta, (3) sebagai bukti untuk mendapat dan layanan dari OWWA, (4) digunakan untuk mengirim uang ke rumah sebagai ATM dan kartu debet. Dengan adanya kartu ini pemerintah lebih mudah mengontrol pemasukan devisa. Kewenangan OWWA adalah untuk melindungi dan mempromosikan kesejahteraan pekerja luar negeri dan tanggungan mereka. The OWWA menyediakan pekerjaan sosial dan program bantuan hukum kepada pekerja luar negeri dan memfasilitasi pelaksanaan Kode Tenaga Kerja, serta Pekerja Migran dan Luar Negeri Filipina Act of 1995.

\section{c. The Office of the Legal Assistant for Migrant Affairs (OLAMA)}

OLAMA merupakan lembaga yang memiliki tugas dan kewenangan untuk membantu dan melindungi TKF yang mendapatkan perlakuan yang tidak adil, baik secara fisik maupun secara psikis. Dalam Republic Act, pemerintah wajib menyediakan 100 juta peso, untuk bantuan hukum/membayar pengacara Republic Act E-ISSN: 2657-0300 Lembaga Penelitian dan Penerbitan Hasil Penelitian Ensiklopedia $\quad 293$ 
juga mengamanatkan pembuatan Resource Centre di negeri yang banyak tenaga kerja Pilipina, Resource Centre berada di bawah duta besar Pilipina tugas non stop 24 jam, 7 hari/minggu. Fungsi resource centre ini (1) melakukan conseliring dan bantuan hukum, (2) memberi bantuan pengobatan dan rumah sakit, (3) menyediakan informasi dan advokasi program mereka yang baru datang dari Pilipina agar bisa menyesuaikan diri dengan masyarakat setempat, (4) menyediakan pelatihan dan tingkat SDM (5) memberi program sensitif gender dan berbagai kegiatan untuk membantu pekerjaan wanita.

Secara individual maupun kolektif, perlindungan migran Filipina pekerja meliputi:

a) pemberdayaan sosial dan budaya: 1) Perlu untuk memperkuat inisiatif dan meningkatkan program-program yang berhubungan dengan spiritual dan sosial dan kebutuhan perawatan kesehatan buruh migran; 2) Perlu untuk mendorong Filipina-Jepang program budaya dan solidaritas difokuskan pada peningkatan keluarga dan nilai-nilai masyarakat serta apresiasi keluarga baik Jepang dan Filipina budaya; 3) Keanggotaan dalam OWWA, SSS dan PAG-ibig baik oleh didokumentasikan dan tidak terdokumentasikan. Hal ini diusulkan bahwa lembaga-lembaga harus mendirikan kantor penyuluhan di Jepang (PNB remittance kantor di Jepang tidak diperbolehkan untuk mengumpulkan untuk SSS dan Pag-ibig bawah Jepang perbankan aturan); 4) Permintaan di kedutaan Filipina untuk memberikan pertolongan pertama dan praktisi medis Filipina, termasuk kesehatan medis khusus, perawatan dan / atau asuransi kelompok untuk tidak berdokumen pekerja, bahasa program pelatihan, keanggotaan khusus dengan SSS, PAG-ibig dan OWWA untuk pekerja tidak berdokumen, dan pemerintah yang didukung konseling dan sementara penampungan; 5) Menuntut bahwa ada menjadi implementasi penuh UU Pekerja Migran ketentuan

Dana bantuan hukum dan dana khusus untuk Filipina dalam kesulitan; dan 6) Permintaan untuk bantuan meningkat dari kedutaan mengenai sistem tahanan di Jepang mengenai anak-anak Filipina-Jepang keturunan dibesarkan di panti asuhan.

b) Pemberdayaan Ekonomi: 1) Organisasi dan penyatuan pekerja Filipina di luar negeri di Jepang untuk mengkonsolidasikan mereka menjadi satu kekuatan besar yang mampu menangani sendiri masalah sosial-ekonomi; 2) Mobilisasi tabungan migran, dengan bantuan dari KAPISANAN, dalam rangka membangun baik masa depan di Filipina; 3) Perlu memiliki sistem sertifikasi dan peningkatan keterampilan yang diperoleh di Jepang dan memiliki sertifikasi tersebut diterima di kedua tuan rumah dan negara asal; 4) Permintaan pemerintah untuk meningkatkan Pra-keberangkatan Seminar Orientasi (PDOS) dalam kaitannya dengan kampanye mobilisasi pemberdayaan dan tabungan; dan 5) Perlu bagi pemerintah untuk memberikan informasi yang lengkap dan bantuan pada alternatif investasi pendekatan, khususnya operasionalisasi OFW tabungan obligasi Program. Pada pemberdayaan ekonomi, tim membahas berbagai pilihan investasi yang ditawarkan oleh pemerintah, yaitu: 1) Obligasi Perumahan SSS Flexi-Dana untuk OFW, 2) dari Rumah Pengembangan Reksa Dana (HDMF) atau PAG-ibig Obligasi bagi Pekerja Luar Negeri, dan 3)Pengentasan Kemiskinan Pemberantasan Sertifikat atau Zero Coupon Bond atau Obligasi Damai membangun Hanap-Buhay (mata pencaharian) Dana. 
c) Politik Pemberdayaan: 1) Semua-out kampanye untuk pemberlakuan hukum mengakui hak Overseas Filipina; 2) Full pengakuan hak hak pilih dan kewarganegaraan bagi warga Filipina yang menikah dengan Jepang warga negara; 3) Ulasan sistem perwakilan dan pengangkatan wakil pekerja migran di POEA, OWWA dan badan-badan lain yang membutuhkan wakil pekerja migran; 4) Kampanye global untuk penyatuan dan organisasi pekerja migran melalui jaringan; 5) Kampanye untuk regularisasi dan legalisasi yang tidak berdokumen melalui amnesti atau penerbitan visa kerja khusus; dan 6) Kebutuhan untuk teratur dan bermakna kedutaan-LSM dialog dan kerjasama dalam operasionalisasi dari Pusat Sumber Daya Filipina dan dalam menanggapi migran utama pekerja masalah dan kekhawatiran.

Perekrutan illegal bila dilakukan oleh sindikat atau dalam skala besar akan dianggap sebagai pelanggaran yang melibatkan sabotase ekonomi. Perekrutan ilegal dianggap dilakukan oleh sindikat jika dilakukan oleh kelompok tiga (3) orang atau lebih bersekongkol atau confederating dengan satu sama lain. Hal ini dianggap dilakukan di skala besar jika dilakukan terhadap tiga (3) orang atau lebih secara individual maupun secara kelompok. Dalam kasus orang yuridis, petugas memiliki kontrol, manajemen atau arah bisnis mereka bertanggung jawab.

Pemerintah memiliki komitmen yang besar dalam melindungi warga negara. Di Singapura pembantu rumah tangga yang dihukum mati di Singapura, memancing krisis politik antar Singapura dan Pilipina. Akhirnya pemerintah Pilipina bertindak menarik duta besar dari Singapura. Untuk melindungi tenaga kerja migran di luar negeri, pemerintah mengharuskan melalui jalan legal, baik melalui POEA atau agen swasta asing, dan pemerintah Pilipina langsung bertanggung jawab sepenuhnya seperti dituntut dalam UU Tenaga Kerja Migran yang disebut Republic Act.

Menurut Undang-Undang Ketenagakerjaan Filipina (Labour Code of the Philippines) yang ditetapkan pada tahun 2009, para pekerja Filipina hanya bisa dikirim ke negara-negara yang memberi perlindungan dan kepastian hukum yang cukup atau yang telah menandatangani perjanjian bilateral. Perjanjian ini pada intinya mencegah terjadinya kasus-kasus perlakukan buruk terhadap para pekerja Filipina. Sejumlah negara di Timur Tengah dan Asia Tenggara, yang dikenal sebagai tujuan utama pekerja Filipina, tidak termasuk dalam daftar hitam pemerintah Filipina. Di negara-negara ini juga muncul kasus perlakukan buruk terhadap pekerja-pekerja asal Filipina. Perusahaan multinasional yang mempekerjakan tenaga terampil di negaranegara yang dilarang akan mendapatkan pengecualian.

\section{Penutup}

Negara Filipina terdapat dalam Section 3 Konstitusi Filipina Tahun 1987 (The 1987 Constitution of the Republic of The Philippines) Pada prinsipnya, pemerintah Filipina memberikan perlindungan yang penuh untuk tenaga kerja, baik tenaga kerja dalam negeri maupun tenaga kerja luar negeri, dan memberikan jaminan hak-hak bagi seluruh tenaga kerjanya. Sistem perlindungan hukum untuk OPW nya, POEA bertanggungjawab penuh Kepada Presidennya melalui Menteri Tenaga Kerja. Hubungan POEA dengan lembaga lainnya yang terkait dengan perlindungan OPWnya bersifat sub koordinatif. POEA menjadi induk bagi perlindungan OPW. Badan atau lembaga perlindungan hukum bagi OFW di Filipina adalah POEA, yang ditugaskan untuk memantau dan mengawasi agen perekrutan di Filipina, OWWA yang menyediakan pekerja migran Filipina dan keluarganya semua bantuan yang mereka E-ISSN: 2657-0300 Lembaga Penelitian dan Penerbitan Hasil Penelitian Ensiklopedia 295 
mungkin perlu dalam penegakan kewajiban kontrak oleh lembaga atau badan dan / atau mereka prinsipal, dan OLAMA memiliki tugas dan kewenangan untuk membantu dan melindungi OPF yang mendapatkan perlakuan yang tidak adil, baik secara fisik maupun secara psikis. Sedangan bentuk perlindungan yang diberikan pemerintah Filipina terhadap OFW adalah memaksimalkan peran dari ketiga lembaga tersebut, memberikan penghargaaan kepada OFW sebagai pahlawan devisa negara dan membuat perjanjian Mou dengan negara penerima serta memberikan bantuan atau pendampingan hukum secara Cuma-Cuma terhadap OFW bermasalah.

\section{Daftar Pustaka}

Asri Wijayanti,2009,Hukum Ketenagakerjaan Pasca Reformasi,Sinar Grafika,Jakarta. Bambang Waluyo,2008,Penelitian Hukum Dalam Praktek, Sinar Grafika,Jakarta.

C.S.T. Kansil,2002,Pengantar Ilmu Hukum Dan Tata Hukum Indonesia,Balai Pustaka,Jakarta.

Jimly Asshiddiqie,2010,Konstitusi \& Konstitusionalisme Indonesia,Sinar Grafika,Jakarta.

Moh.MD,2001,Politik Hukum Indonesia,PT Pustaka LP3ES,Jakarta.

Satjipto Rahardjo,2000,Ilmu Hukum,PT Citra Aditya Bakti,Bandung.

Soerjono Soekanto dan Sri Mamuji,1990,Penelitian Hukum Normatif:Suatu Tinjauan Singkat,Rajawali Press,Jakarta.

Zainuddin Ali,2009,Metode Penelitian Hukum, Sinar Grafika,Jakarta.

Jurnal hukum, perlindungan hukum bagi buruh migrant terhadap tindakan perdagangan perempuan, devi rahayu, no.1 vol 18 januari 2011.

Majalah hukum nasional, No 1 Tahun 2004, menakar perlindungan hukum normative pekerja/buruh dalam industrialisasi, Teguh Sulistia.

Jurnal HAM vol 2 no 1 april 2005, pemenuhan dan perlindungan hak tenaga kerja Indonesia ke luar negeri pada proses pra penempatan (tinjauan hasil penelitian), Oki Wahju Budijanto

Hotma p. Sibuea,2010, asas negara hukum, peraturan kebijakan dan asas-asas umum pemerintahan yang baik, erlangga, Jakarta

Pamudji,1983, perbandingan pemerintahan, PT Bina Aksara, Jakarta

Zainal Asikin,dkk , Dasar-Dasar Hukum Perburuhan, PT Raja Grafindo Persada, Jakarta 1993

Jazim Hamidi dan Mustafa Ali,2009,Ketentuan Konstitusioanal Pemberlakuan Keadaan Darurat Dalam Suatu Negara,Jurnal Konstitusi,Volume 6 Nomor 1, April

Kertas Kerja Human Rights Working Group (HWG), 2010,Ratifikasi Konvensi Perlindungan Hak Semua Buruh Migran dan Anggota Keluarganya! Belajar Dari Meksiko,Perpustakaan Nasional RI : Katalog Dalam Terbitan (KDT) HRWG, Tim

Raditya.Filipina Larang Warga Bekerja di 41 Negara. http:// BBC Indonesia/,filipinalarang-warga-bekerja-di-41-negara.htm.diakses pada tanggal 14 Juni 2012

Amri Margatama.Upah Minimum Gaji Tenaga Kerja Filipina. http://Google/UpahMinimum-Flipina-international-gaji-minimal-rata-2012.htm diakses pada tanggal 23 Juli 2020

SatriaDewantara.Lagi.TKIMeninggalDianiaya.http://kompas.com/Lagi.TKI.Meninggal .Dianiaya.htm,diakses pada tanggal 23 Juli 2020 